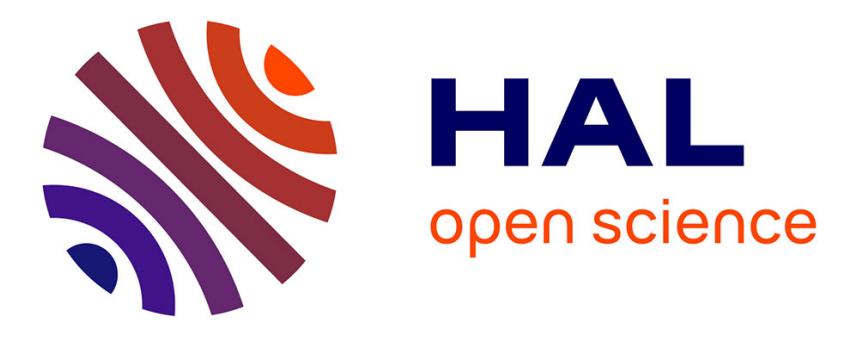

\title{
Synthesis of a Novel Rhizobitoxine-Like Triazole-Containing Amino Acid
}

Thibaut Boibessot, David Bénimélis, Marion Jean, Zohra Benfodda, Patrick Meffre

\section{- To cite this version:}

Thibaut Boibessot, David Bénimélis, Marion Jean, Zohra Benfodda, Patrick Meffre. Synthesis of a Novel Rhizobitoxine-Like Triazole-Containing Amino Acid. SYNLETT, 2016, 27 (19), pp.2685-2688. 10.1055/s-0036-1588300 . hal-01404310

\section{HAL Id: hal-01404310 https://hal.science/hal-01404310}

Submitted on 28 Nov 2016

HAL is a multi-disciplinary open access archive for the deposit and dissemination of scientific research documents, whether they are published or not. The documents may come from teaching and research institutions in France or abroad, or from public or private research centers.
L'archive ouverte pluridisciplinaire HAL, est destinée au dépôt et à la diffusion de documents scientifiques de niveau recherche, publiés ou non, émanant des établissements d'enseignement et de recherche français ou étrangers, des laboratoires publics ou privés. 


\section{Synthesis of a Novel Rhizobitoxine-Like Triazole-Containing Amino Acid}

\author{
Thibaut Boibessot ${ }^{a}$ \\ David Bénimèlis \\ Marion Jean ${ }^{b}$ \\ Zohra Benfodda ${ }^{a}$ \\ Patrick Meffre*a \\ a Université de Nîmes, EA7352 CHROME, \\ Rue du Dr G. Salan, 30021 Nîmes Cedex 1, France \\ patrick.meffre@unimes.fr \\ b Aix Marseille Univ, CNRS, Centrale Marseille, iSm2, \\ Marseille, France
}

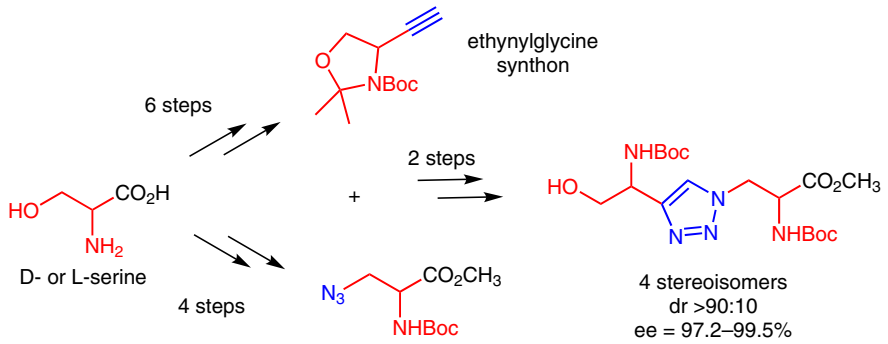

therefore have potential applications in agronomy and biotechnology. ${ }^{13,14}$

Synthesis of such unusual amino acids is a challenge, especially because of the enol ether reactivity. ${ }^{1,15,16}$ Therefore, there is a need for readily accessible stable structural analogues. 1,2,3-Triazole derivatives have gained a recent interest in medicinal chemistry because they are pharmacophores with good stability and high aqueous solubility, ${ }^{17-21}$ particularly in the area of peptidomimetics ${ }^{22}$ and are readily accessible by the Huisgen 1,3-dipolar cycloaddition involving an alkyne and an azide. ${ }^{23-26}$

In this paper, we describe the synthesis of a new triazole-containing amino acid analogue of rhizobitoxine in protected form (compound $(1 S, 2 S)$-2) from serine (Figure 2) where the central enol ether linkage in rhizobitoxine is replaced by the robust 1,2,3-triazole linker in such a way that there is no longer $\beta, \gamma$-unsaturation to the amino acid moiety. This analogue should be a stable analogue compared to unstable vinylglycine derivatives and, based on reported mechanisms of inhibition, such an unusual amino acid could be a potential inhibitor of PLP-dependent enzymes. ${ }^{27,28}$

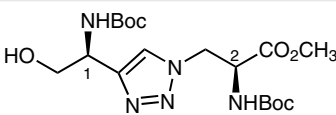

Figure 2 Protected triazole containing analogue of rhizobitoxine $[(1 S, 2 S)-2]$

Retrosynthetic analysis shows that this compound should be accessible using a Huisgen 1,3-dipolar cycloaddition of azide $(S)-\mathbf{3}$ with alkyne $(S)-\mathbf{4}$ (Figure 3 ).

Alkyne (S)-4 is an 'ethynylglycine synthon'. ${ }^{29,30}$ It is synthesized from D-serine in six steps using Garner aldehyde $(R)-5^{31,32}$ as a key precursor (Scheme 1 ). Two principal methods have been described to synthesize alkyne $\mathbf{4}$ from 
<smiles></smiles>

$(S)-4$
(S)-3<smiles>CC(=O)OC(CN)C(N)C(=O)OCc1ccccc1</smiles>

Figure 3 Precursors of the Huisgen 1,3-dipolar cycloaddition for triazole formation in (1S,2S)-2

aldehyde 5: the Bestmann-Ohira and the the Corey-Fuchs strategies. $^{29}$ We decided here to use the Bestmann-Ohira strategy using diazophosphonate $\mathbf{6}$ for this aldehyde-toalkyne transformation, as this was well-known in our laboratory. ${ }^{33}$ In 2002, we described the one-pot synthesis of ethynylglycine synthon 4 in $70 \%$ in 72 hours. ${ }^{34}$ This procedure involving in situ formation of diazophosphonate $\mathbf{6}$ is convenient on a small scale $(0.95 \mathrm{mmol}$ of aldehyde 5 ) but we noticed a dramatic increase of the reaction time when performed on a larger scale. Therefore, we decided to return to the original strategy ${ }^{35}$ with preparation of diazophosphonate $\mathbf{6}$ prior to the homologation. After flash chromatography, the ethynylglycine synthon 4 was obtained in $83 \%$ yield on $22 \mathrm{mmol}$ scale (lit. ${ }^{35} 80 \%$ on $11 \mathrm{mmol}$ scale) (Scheme 1).

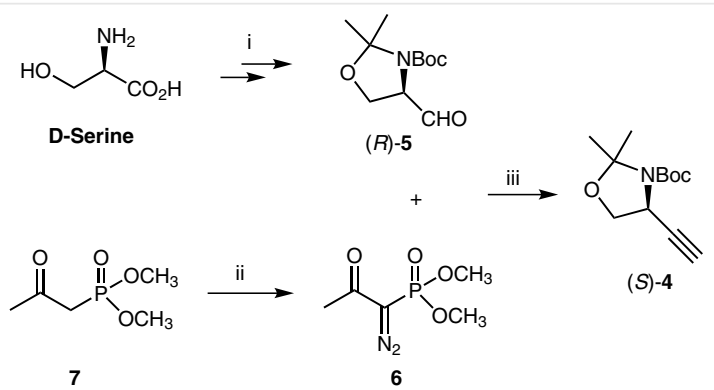

Scheme 1 Reagents and conditions: (i) see ref. ${ }^{31,32}$; (ii) NaH, toluene then 4-acetamidobenzenesulfonyl azide, THF, $72 \%$, see ref. ${ }^{36}$; (iii) $\mathrm{K}_{2} \mathrm{CO}_{3}$, $\mathrm{MeOH}, 83 \%$

The diazophosphonate $\mathbf{6}$ was synthesized from phosphonate 7 with minor modifications of the procedure described by Pietruszka and Witt. ${ }^{36}$ It was obtained in $72 \%$ yield (lit. ${ }^{36} 77 \%$ ) (Scheme 1).

Azide $(S)$-3 was synthesized from protected L-serine $(S)$ 8. ${ }^{31}$ We first envisaged synthesizing azide 3 by a nucleophilic substitution on reactive sulfonic ester derivatives of alcohol 8 (Scheme 2). The conversion of alcohol $(S)-\mathbf{8}$ into $p$-toluenesulfonate $(S)-9 a$ was performed using the conditions described by Jackson and Perez-Gonzales ${ }^{37}$ to obtain (S)-9a in $68 \%$ yield, and the results were in agreement with the literature (lit. ${ }^{37}$ 64-69\%). Conversion of $(S)$-8 into methanesulfonate $(S)-\mathbf{9 b}$ was performed using the conditions of Shetty et al. ${ }^{38}$ and allowed $(S)-9 b$ to be obtained in $64 \%$ yield after column chromatography purification (lit. ${ }^{38} 81 \%$, crude

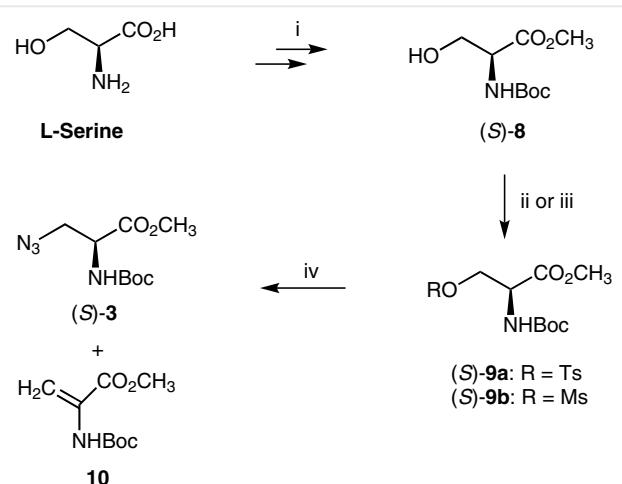

Scheme 2 Reagents and conditions: (i) see ref. ${ }^{31}$; (ii) $\mathrm{TsCl}^{-} \mathrm{Et}_{3} \mathrm{~N}, 4-\mathrm{DMAP}$ (cat.), $\mathrm{Me}_{3} \mathrm{NHCl}$ (cat.), $\mathrm{CH}_{2} \mathrm{Cl}_{2}, 0^{\circ} \mathrm{C}, 2 \mathrm{~h}, 68 \%$; (iii) $\mathrm{MsCl}, \mathrm{Et}_{3} \mathrm{~N}, \mathrm{CH}_{2} \mathrm{Cl}_{2}, 0^{\circ} \mathrm{C}$, 0.5 h, 64\%; (iv) $\mathrm{NaN}_{3}$, DMF, see Table 1.

yield). The results of the transformation from $(S)-9 a$ and $(S)-\mathbf{9 b}$ to $(S)-\mathbf{3}$ are summarized in Table 1 . The best reaction conditions in our hands for nucleophilic substitution were using sodium azide in DMF at $70{ }^{\circ} \mathrm{C}$ for a short reaction time (Table 1 , entry 2 ). Under these reaction conditions, azide $(S)$-3 was obtained from $p$-toluenesulfonate $(S)-9 a$ in $39 \%$ yield, together with alkene 10 in 37\% yield, resulting from an elimination reaction. Changing from $p$-toluenesulfonate 9a to methanesulfonate $\mathbf{9 b}$, or lowering reaction temperature did not improve the yield for $\mathbf{3}$ (Table 1 ). We obtained enantiomer $(R)-3$ under the same conditions (Table 1 , entry 2 ) through $(R)-9 a$ from D-serine with identical yields and opposite specific rotation. It is worth noting that Shelly et al. ${ }^{38}$ reported the formation of compound $(S)-3$ from methanesulfonate $(S)-\mathbf{9 b}\left(\mathrm{NaN}_{3}, \mathrm{DMF}, 50{ }^{\circ} \mathrm{C}, 0.5 \mathrm{~h}\right.$; under the same conditions as Table 1, entry 4 ) in $56 \%$ yield but with a lower specific rotation. Moreover, Friscourt et al. reported the formation of the benzyl ester analogue of 3 $\left(\mathrm{NaN}_{3}, \mathrm{DMF}, 40^{\circ} \mathrm{C}, 2 \mathrm{~h}\right)$ in only $18 \%$ yield. ${ }^{39}$ All these observations show that this transformation is somewhat capricious.

Table 1 Results of the $\mathrm{NaN}_{3}$ Nucleophilic Substitution on (S)-9a and (S)-9 $\mathbf{b}^{\mathrm{a}}$

\begin{tabular}{lccccc}
\hline Entry & $\begin{array}{c}\text { Starting } \\
\text { material }\end{array}$ & $\mathrm{T}\left({ }^{\circ} \mathrm{C}\right)$ & Time (h) & $\begin{array}{l}\text { Yield of } \\
(S)-3(\%)\end{array}$ & $\begin{array}{l}\text { Yield of } \\
10(\%)\end{array}$ \\
\hline 1 & $(S)-9 a$ & 20 & 5 & 33 & 35 \\
2 & $(S)-9 a$ & 70 & 0.17 & 39 & 37 \\
3 & $(S)-9 b$ & 20 & 24 & 25 & 55 \\
4 & $(S)-9 b$ & 50 & 0.5 & 25 & 29 \\
\hline
\end{tabular}

a See Scheme 2, reaction conditions (iv).

We then tried the direct formation of azide $(S)$-3 using a Mitsunobu reaction as described by Stanley et al. ${ }^{40}$ (Scheme 3 ). 
<smiles>CC(=O)NC(CO)C(=O)OC(C)=O</smiles>

(S)-8

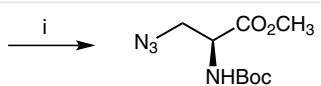

(S)-3
Scheme 3 Reagents and conditions: (i) $\mathrm{Ph}_{3} \mathrm{P} / \mathrm{DIAD} / \mathrm{DPPA}$ (1.14/1.28/1.14), THF, $0{ }^{\circ} \mathrm{C}, 41 \%$.

Azide (S)-3 was obtained in 41\% yield from (S)-8 (lit.40 $69 \%$ ) although with a cumbersome purification by column chromatography to isolate a somewhat impure material as observed on the NMR spectrum. We decided therefore to pursue the synthesis using pure compound 3 obtained following conditions described in Scheme 2,Table 1, entry 2.

To the best of our knowledge, there is only one precedent describing a Huisgen 1,3-dipolar cycloaddition using an ethynylglycine synthon as substrate. It is one example (with no further application of the product) in a methodology report of a click reaction between in situ generated $\beta$-azido styrenes from cinnamic acid using $\mathrm{CAN} / \mathrm{NaN}_{3}$ and alkynes to form $N$-styryl triazoles. ${ }^{41}$

The Huisgen 1,3-dipolar cycloaddition between ethynylglycine synthon (S)-4 and azide $(S)-\mathbf{3}$ was performed using classical conditions ${ }^{42}$ (Scheme 4, path a): LAscorbate, $\mathrm{CuSO}_{4}$ in the mixture of tert-butanol/water and yielded the desired 1,2,3-triazole (2S,4S)-11 in $70 \%$ yield. Deprotection of the oxazolidine with APTS monohydrate in methanol ${ }^{43}$ furnished the final compound $(1 S, 2 S)-2$ in $17 \%$ yield with $55 \%$ recovery of starting material. The overall yield from $(S)-\mathbf{4}$ was $12 \%$.

In order to increase the global yield, inversion of the order of the two final steps was examined (Scheme 4, path b). Opening the oxazolidine ring in (S)-4 using the same conditions as before yielded the protected amino alcohol $(S)-\mathbf{1 2}$ in $48 \%$ yield with recovery of starting material (S)-4 in $32 \%$ yield. Subsequent Huisgen cycloaddition then led to the same compound $(1 S, 2 S)-2$ in $65 \%$ yield, with a $92: 8$ diastereomeric ratio and an enantiomeric excess higher than $99.5 \%$ (vide infra). Using this strategy, the overall yield from (S)-4 increased to $31 \%$.

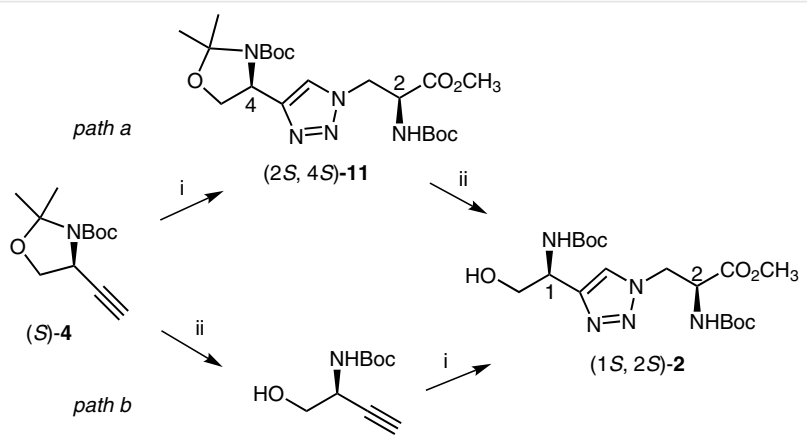

(S)-12

Scheme 4 Reagents and conditions: (i) azide (S)-3, L-ascorbate (0.2 equiv), $\mathrm{CuSO}_{4}$ (0.1 equiv), $t-\mathrm{BuOH}-\mathrm{H}_{2} \mathrm{O}(1: 1), 70 \%$, (path a), $65 \%$ (path b); (ii) PTSA- $\mathrm{H}_{2} \mathrm{O}, \mathrm{MeOH}, 20^{\circ} \mathrm{C}, 2 \mathrm{~h}, 17 \%$ (path a), $48 \%$ (path b).
The four stereoisomers of compound $\mathbf{2}$ were synthesized using the same strategy as described above from Dand L-serine with analogous results (see Supporting Information). ${ }^{44}$

After a screening of several chiral stationary phases by HPLC, Lux-Cellulose-2, and Chiralpak AZ-H were found to be efficient for baseline separation of the mixture of the four stereoisomers of $\mathbf{1 1}$ and $\mathbf{2}$, respectively, thus allowing the determination of the diastereomeric ratio and the enantiomeric excess of each isomer (Table 2). For all compounds, diastereomeric ratios were found to be greater than 90:10 and the enantiomeric excesses were higher than 96\% (see Supporting Information)

Table 2 Diastereomeric Ratio and Enantiomeric Excess for Stereoisomers of $\mathbf{1 1}$ and $\mathbf{2}$

\begin{tabular}{lrrlrl}
\hline Isomer & $\mathrm{dr}$ & ee $(\%)$ & Isomer & $\mathrm{dr}$ & ee $(\%)$ \\
\hline$(2 S, 4 R)-\mathbf{1 1}$ & $10: 1$ & 99.5 & $(1 S, 2 S)-\mathbf{2}$ & $11: 1$ & 99.5 \\
$(2 R, 4 S)-\mathbf{1 1}$ & $16: 1$ & 96.2 & $(1 R, 2 R)-\mathbf{2}$ & $10: 1$ & 99.5 \\
$(2 S, 4 S)-\mathbf{1 1}$ & $14: 1$ & 99.5 & $(1 S, 2 R)-\mathbf{2}$ & $14: 1$ & 99.5 \\
$(2 S, 4 R)-\mathbf{1 1}$ & $9: 1$ & 99.5 & $(1 R, 2 S)-\mathbf{2}$ & $9: 1$ & 97.2
\end{tabular}

a Determined by chiral HPLC.

Deprotection of compounds $\mathbf{2}$ and biological evaluation of their activity on PLP-dependant enzymes are under investigation in our laboratory, and the results will be reported in due course.

\section{Acknowledgment}

We gratefully thank the French 'Ministère de l'Éducation Nationale, de l'Enseignement Supérieur et de la Recherche' for financial support. Dr Nicolas Vanthuyne (Aix-Marseille Université, Plateforme de Chromatographie Chirale, ISM2 - UMR7313 - Chirosciences) is acknowledged for fruitful collaboration.

\section{Supporting Information}

Supporting information for this article is available online at http://dx.doi.org/10.1055/s-0036-1588300.

\section{References and Notes}

(1) Berkowitz, D. B.; Charette, B. D.; Karukurichi, K. R.; McFadden, J. M. Tetrahedron: Asymmetry 2006, 17, 869.

(2) Erdman, L. W.; Johnson, H. W.; Clark, F. Plant Dis. Rep. 1956, 646.

(3) Owens, L. D.; Wright, D. A. Plant Physiol. 1965, 40, 927.

(4) Okazaki, S.; Sugawara, M.; Yuhashi, K.-I.; Minamisawa, K. Ann. Bot. 2007, 100, 55.

(5) Owens, L. D.; Guggenheim, S.; Hilton, J. L. Biochim. Biophys. Acta, Gen. Subj. 1968, 158, 219. 
(6) Owens, L. D.; Thompson, J. F.; Pitcher, R. G.; Williams, T. J. Chem. Soc., Chem. Commun. 1972, 714.

(7) Yasuta, T.; Okazaki, S.; Mitsui, H.; Yuhashi, K.-I.; Ezura, H.; Minamisawa, K. Appl. Environ. Microbiol. 2001, 67, 4999.

(8) Mitchell, R. E.; Frey, E. J.; Benn, M. H. Phytochemistry 1986, 2711.

(9) Xiong, K.; Fuhrmann, J. J. Plant Soil 1996, 186, 53.

(10) Yasuta, T.; Satoh, S.; Minamisawa, K. Appl. Environ. Microbiol. 1999, 65, 849 .

(11) Owens, L. D.; Lieberman, M.; Kunishi, A. Plant Physiol. 1971, 48, 1.

(12) Sugawara, M.; Okazaki, S.; Nukui, N.; Ezura, H.; Mitsui, H.; Minamisawa, K. Biotechnol. Adv. 2006, 24, 382.

(13) Villalobos-Acuña, M.; Mitcham, E. J. Postharvest Biol. Technol. 2008, 49, 187.

(14) Hirase, K.; Molin, W. T. Weed Biol. Manage. 2003, 3, 147.

(15) Daumas, M.; Vo-Quang, L.; Le Goffic, F. Tetrahedron 1992, 48, 2373.

(16) Keith, D. D.; Tortora, J. A.; Ineichen, K.; Leimgruber, W. Tetrahedron 1975, 31, 2633.

(17) Agalave, S. G.; Maujan, S. R.; Pore, V. S. Chem. Asian J. 2011, 6, 2696.

(18) Hein, C. D.; Liu, X.-M.; Wang, D. Pharm. Res. 2008, 25, 2216.

(19) Sahu, J. K.; Ganguly, S.; Kaushik, A. Chin. J. Nat. Med. 2013, 11, 456.

(20) Kumar, D.; Reddy, V. B.; Kumar, A.; Mandal, D.; Tiwari, R.; Parang, K. Bioorg. Med. Chem. Lett. 2011, 21, 449.

(21) Lebeau, A.; Abrioux, C.; Bénimèlis, D.; Benfodda, Z.; Meffre, P. Med. Chem. 2016, 12, DOI: 10.2174/1573406412666160404125718.

(22) Valverde, I. E.; Mindt, T. L. Chimia 2013, 67, 262.

(23) Huisgen, R. Angew. Chem., Int. Ed. Engl. 1963, 2, 565.

(24) Rostovtsev, V. V.; Green, L. G.; Fokin, V. V.; Sharpless, K. B. Angew. Chem. Int. Ed. 2002, 41, 2596.

(25) Kumar, D.; Reddy, V. B.; Varma, R. S. Tetrahedron Lett. 2009, 50, 2065.

(26) Totobenazara, J.; Burke, A. J. Tetrahedron Lett. 2015, 56, 2853.

(27) Walsh, C. Tetrahedron 1982, 38, 871.

(28) Rando, R. R. Pharmacol. Rev. 1984, 36, 111.

(29) Benfodda, Z.; Bénimélis, D.; Reginato, G.; Meffre, P. Amino Acids 2015, 47, 271 .

(30) Reginato, G.; Meffre, P.; Gaggini, F. Amino Acids 2005, $29,81$.

(31) Garner, P.; Park, J. M. Org. Synth. 1992, 70, 18.

(32) Dondoni, A.; Perrone, D. Org. Synth. 2000, 77, 64.

(33) Meffre, P.; Gauzy, L.; Perdigues, C.; Desanges-Levecque, F.; Branquet, E.; Durand, P.; Le Goffic, F. Tetrahedron Lett. 1995, 36, 877.

(34) Meffre, P.; Hermann, S.; Durand, P.; Reginato, G.; Riu, A. Tetrahedron 2002, 58, 5159.

(35) Meffre, P.; Gauzy, L.; Branquet, E.; Durand, P.; Le Goffic, F. Tetrahedron 1996, 52, 11215.

(36) Pietruszka, J.; Witt, A. Synthesis 2006, 4266.

(37) Jackson, R. F. W.; Perez-Gonzalez, M. Org. Synth. 2005, 81, 77.

(38) Shetty, D.; Jeong, J. M.; Ju, C. H.; Kim, Y. J.; Lee, J.-Y.; Lee, Y.-S.; Lee, D. S.; Chung, J.-K.; Lee, M. C. Bioorg. Med. Chem. 2010, 18, 7338.

(39) Friscourt, F.; Fahrni, C. J.; Boons, G.-J.J. Am. Chem. Soc. 2012, 134, 18809.

(40) Stanley, N. J.; Pedersen, D. S.; Nielsen, B.; Kvist, T.; Mathiesen, J. M.; Bräuner-Osborne, H.; Taylor, D. K.; Abell, A. D. Bioorg. Med. Chem. Lett. 2010, 20, 7512.
(41) Kavitha, M.; Mahipal, B.; Mainkar, P. S.; Chandrasekhar, S. Tetrahedron Lett. 2011, 52, 1658.

(42) Gajewski, M.; Seaver, B.; Esslinger, C. S. Bioorg. Med. Chem. Lett. 2007, 17, 4163.

(43) Goswami, K.; Duttagupta, I.; Sinha, S. J. Org. Chem. 2012, 77, 7081.

(44) General Synthetic Procedure for Click-Chemistry Reaction for the Synthesis of 2

(S)-Methyl 2-[(tert-Butoxycarbonyl)amino]-3-(4-\{(S)-1[(tert-butoxycarbonyl)amino]-2-hydroxyethyl\}-1H-1,2,3triazol-1-yl)propanoate [(1S,2S)-2, (Scheme 4, Path a]

To a solution of $(2 S, 4 S)-\mathbf{1 1}(0.337 \mathrm{~g}, 0.72 \mathrm{mmol})$ in $\mathrm{MeOH}(5 \mathrm{~mL})$ was added PTSA. $\mathrm{H}_{2} \mathrm{O}(0.137 \mathrm{~g}, 0.72 \mathrm{mmol})$. The reaction mixture was stirred for $2 \mathrm{~h}$ at room temperature and sat. aq $\mathrm{NaHCO}_{3}$ solution $(40 \mathrm{~mL})$ was poured into the solution. The aqueous solution was extracted with EtOAc $(3 \times 40 \mathrm{~mL})$. The organic phases were combined, washed with sat. aq $\mathrm{NaHCO}_{3}$ solution $(40 \mathrm{~mL})$, sat. aq $\mathrm{NaCl}$ solution $(40 \mathrm{~mL})$, dried over $\mathrm{MgSO}_{4}$, filtered, and concentrated under reduced pressure. The residue was purified by flash column chromatography (silica gel, EtOAc-PE $=0: 100$, increasing to $100: 0, v / v$ ) to give the desired compound (1S, 2S)-2 (0.053 g, 17\%) as a white solid and recovered starting material $(2 S, 4 S)-\mathbf{1 1}(0.184 \mathrm{~g}, 55 \%)$.

\section{Analytical Data}

$R_{f}=0.26$ (EtOAc); mp 55-57 ${ }^{\circ} \mathrm{C} .{ }^{1} \mathrm{H} \mathrm{NMR}\left(300 \mathrm{MHz}, \mathrm{CDCl}_{3}\right): \delta=$ $1.42\left[\mathrm{~s}, 18 \mathrm{H}, \mathrm{C}\left(\mathrm{CH}_{3}\right)_{3}\right], 2.89$ (br s, $\left.1 \mathrm{H}, \mathrm{OH}\right), 3.79\left(\mathrm{~s}, 3 \mathrm{H}, \mathrm{CO}_{2} \mathrm{CH}_{3}\right)$, 3.84-3.87, 4.10-4.12 (2 m, $\left.2 \mathrm{H}, \mathrm{CH}_{2} \mathrm{O}\right), 4.70-4.86(\mathrm{~m}, 4 \mathrm{H}, 2 \mathrm{CH}$, $\left.\mathrm{CH}_{2} \mathrm{~N}\right), 5.43(\mathrm{br} \mathrm{s}, 1 \mathrm{H}, \mathrm{NH}), 5.59(\mathrm{br} \mathrm{s}, 1 \mathrm{H}, \mathrm{NH}), 7.57\left(\mathrm{~s}, 1 \mathrm{H}, \mathrm{CH}_{\text {tri- }}\right.$ azole). ${ }^{13} \mathrm{C}$ NMR $\left(75 \mathrm{MHz}, \mathrm{CDCl}_{3}\right): \delta=28.4,28.5[2 \mathrm{~s}, 18 \mathrm{H}$, $\left.\mathrm{C}\left(\mathrm{CH}_{3}\right)_{3}\right], 48.2(\mathrm{CH}), 51.5\left(\mathrm{CH}_{2} \mathrm{~N}\right), 53.4\left(\mathrm{CO}_{2} \mathrm{CH}_{3}\right), 53.9(\mathrm{CH}), 65.0$ $\left(\mathrm{CH}_{2} \mathrm{O}\right), 80.1\left[\mathrm{C}\left(\mathrm{CH}_{3}\right)_{3}\right], 81.0\left[\mathrm{C}\left(\mathrm{CH}_{3}\right)_{3}\right], 123.9\left(\mathrm{CH}_{\text {triazole }}\right), 147.1$ $\left(\mathrm{C}_{\text {triazole }}\right), 155.2\left(\mathrm{NCO}_{2}\right), 155.8\left(\mathrm{NCO}_{2}\right), 169.5\left(\mathrm{CO}_{2} \mathrm{CH}_{3}\right) \cdot[\alpha]_{\mathrm{D}}{ }^{20}$ +49.9 (c $0.91, \mathrm{CHCl}_{3}$ ). HRMS $\left(\mathrm{ES}^{+}\right): \mathrm{m} / z[\mathrm{M}+\mathrm{H}]^{+}$calcd for $\mathrm{C}_{18} \mathrm{H}_{32} \mathrm{~N}_{5} \mathrm{O}_{7}$ : 430.2302; found: 430.2303. HPLC: purity $=99.6 \%$, $t_{\mathrm{R}}=12.43 \mathrm{~min}$. IR: $3358,2362,2338,1742,1683 \mathrm{~cm}^{-1}$.

Nitrogen inversion in the oxazolidine ring or slow interconversion of both amide or carbamate conformers of compounds $\mathbf{4}$, 11, and 2 causes considerable line broadening and duplication of signals in the ${ }^{1} \mathrm{H}$ NMR and ${ }^{13} \mathrm{C}$ NMR spectra (see Supporting Information).

General Synthetic Procedure for Click-Chemistry Reaction for the Synthesis of 2

(S)-Methyl 2-[(tert-Butoxycarbonyl)amino]-3-(4-\{(S)-1-[(tertbutoxycarbonyl)amino]-2-hydroxyethyl\}-1H-1,2,3-triazol-1yl)propanoate $[(1 S, 2 S)-2$, Scheme 4, Path b)

Azide $3(0.420 \mathrm{~g}, 1.72 \mathrm{mmol})$ and alkyne $12(0.318 \mathrm{~g}, 1.72$ $\mathrm{mmol})$ were dissolved in a mixture of $t-\mathrm{BuOH}-\mathrm{H}_{2} \mathrm{O}(10 \mathrm{~mL}, 1: 1$, $\mathrm{v} / \mathrm{v})$. Sodium L-asborbate $(0.068 \mathrm{~g}, 20 \mathrm{~mol} \%)$ and $\mathrm{CuSO}_{4} \cdot 5 \mathrm{H}_{2} \mathrm{O}$ $(0.041 \mathrm{~g}, 10 \mathrm{~mol} \%)$ were added. The reaction mixture was stirred at room temperature for $24 \mathrm{~h}$, the solution was concentrated under vacuum and diluted with $\mathrm{H}_{2} \mathrm{O}(70 \mathrm{~mL})$. The aqueous phase was extracted with EtOAc $(3 \times 50 \mathrm{~mL})$. The organic phases were combined, dried over $\mathrm{MgSO}_{4}$, filtered, and concentrated under reduced pressure. The residue was purified by flash chromatography (silica gel, EtOAc-PE $=0: 100$, increasing to $100: 0, v / v)$ to give the desired compound $(1 S, 2 S)-2$ as a white solid $(0.480 \mathrm{~g}, 65 \%$ yield). The compound exhibited the same analytical properties as described above.

See Supporting Information for the characterization data of other products. 